\title{
Clonal building, simple growth rules and phylloclimate as key steps to develop functional-structural seagrass models
}

\author{
Fernando G. Brun ${ }^{1,2, *}$, Juan J. Vergara ${ }^{1}$, Gloria Peralta ${ }^{1}$, Maria Paz García-Sánchez ${ }^{1}$, \\ Ignacio Hernández ${ }^{1}$, J. Lucas Pérez-Lloréns ${ }^{1}$
}

\author{
${ }^{1}$ Departamento de Biología, Área de Ecología, Universidad de Cádiz, Facultad de Ciencias del Mar y Ambientales, \\ 11510 Puerto Real, Cádiz, Spain
}

${ }^{2}$ Present address: Netherlands Institute of Ecology (NIOO-KNAW), Centre for Estuarine and Marine Ecology, Korringaweg 7, 4401 NT Yerseke, The Netherlands

\begin{abstract}
The repetitive clonal growth of the seagrasses Zostera noltii Hornem. and Cymodocea nodosa Aschers at the module level was used to implement a deterministic, individual-based, numerical model using the simplest growth rules. Inter- and intraspecific variability in plant morphology and meadow attributes was simulated, and the results yielded by the model were compared with an existing large data set recorded for both species. The model outputs showed that intra- and interspecific morphological variability can be accurately described $(r=0.99, p<0.0001, n=19)$ by a restricted number of parameters (plastochrone interval [PI] and elongation rates for rhizome [RER] and leaf [LER], which are species-specific parameters). Interspecific differences in meadow properties were recorded; however, simulated values were double those observed. This result was mainly attributable to a lack of densitydependence phenomena in the model assumptions, revealing the importance of such phenomena in structuring seagrass populations. In general, species with high PIs displayed longer modules (leaves and internodes) and lower shoot densities, whereas species with lower PI values developed shorter modules and crowded stands. This result corresponds with the relationship indicated by the self-thinning law and by previous studies. The model also showed that plant morphology arises as an emergent property of a simple set of growth rules acting at the module level, and that plant dynamic parameters can be tuned by seagrasses in response to their local environmental conditions. Thus, the whole-plant response to the environment can be determined by the sum of all the modular responses. This model, together with a better knowledge of the regulation of plant dynamic parameters by control variables (light, temperature, nutrients, etc.), provides a conceptual framework that allows the incorporation of module, plant morphology and meadow properties into functional-structural seagrass models, in which feedbacks among plant morphology, plant development and phylloclimate (i.e. the physical environment actually perceived by each individual organ or plant population) can be included.
\end{abstract}

KEY WORDS: Cymodocea nodosa $\cdot$ Zostera noltii $\cdot$ Clonal growth $\cdot$ Light reduction $\cdot$ Nutrient enrichment Plant dynamic parameters $\cdot$ Plastochrone interval $\cdot$ Rhizome-elongation rate $\cdot$ Leaf-elongation rate

\section{INTRODUCTION}

Seagrasses are benthic organisms living anchored to the sediment, and are thus unable to escape from adverse environmental conditions. This implies that plants have to sense their surroundings or 'phylloclimate variables' (i.e. the physical environment actually perceived by each individual organ [including both aerial and subterranean tissues] or plant population; Chelle 2005) and respond to their environment 
through modifications in metabolical, physiological and/or morphological features (Horn 1971, Oborny 2004). Besides the metabolical and/or physiological adaptations, a high degree of morphological plasticity (the outcome of alterations in growth patterns) in clonal plants has been interpreted as a plant phenotypic response to manage resource heterogeneity in spatial and temporal scales (Schlichting 1986, Oborny 1994, 2004, Stuefer et al. 1994, Huber et al. 1999, Hemminga \& Duarte 2000, Sultan 2000, Urbas \& Zobel 2000). Alterations in morphology go beyond simple morphometric changes, since morphotypes and certain physiological traits are usually linked (e.g. higher photosynthesis and respiration rates in short-leaved than in large-leaved morphotypes of the seagrass Zostera noltii; Pérez-Lloréns \& Niell 1993, Peralta et al. 2000, 2005). Thus, plant morphological acclimation habitually enhances the fitness of the genotype to the environment in some features, but also may reduce the fitness in other underlying traits (see reviews by DeWitt et al. 1998 and Alpert \& Simms 2002). Despite the importance of plant morphological acclimation in the physiology and ecology of seagrasses, it has not been explored in detail.

One of the simplest general views of clonal plant form is that individuals are formed by an iteration of a basic structural module (Harper \& Bell 1979, White 1979). In seagrasses, considering the 'module' definition provided by Waller (1986: 'to refer to any-less-than independent component of an independent whole'), the basic structural module would be arranged by a piece of rhizome (internode) and a node bearing a cluster of leaves (shoot) and roots. This simple organisation together with the clonal integration, give plants the ability to take independent actions at the modular level, such as the allocation of new modules in resource-rich areas to acquire resources from a micropatch environment by a single clone (Oborny 1994, Evans \& Cain 1995, Groenendael et al. 1996, Grime \& Mackey 2002). Consequently, whole-plant morphology can arise as an emergent property based on a set of simple growth rules acting at the individual module level which, in turn, are species-specific traits. Changes in morphological and architectural properties can affect competitive ability, resource acquisition, foraging behaviour and network development (Slade \& Hutchings 1987, de Kroon \& Shieving 1991, Herben \& Suzuki 2001, Oborny et al. 2001). However, the extent to which species-specific clonal-growth rules affect morphological plasticity and meadow attributes have received little attention in seagrasses, and only the latter has been investigated (Marbà \& Duarte 1998, Sintes et al. 2005).

Inter- and intraspecific variability in morphology (the latter commonly referred in seagrass literature as 'mor- photypes') and in growth-related parameters (i.e. 'dynamic properties') have usually been observed under diverse environmental conditions (Backman \& Barilotti 1976, Short 1983, Pérez-Lloréns \& Niell 1993, van Lent \& Verschuure 1994a,b, Peralta et al. 2000, 2005, Brun et al. 2003a). Some of these morphological responses seem to be environmentally driven, as earlier hypothesised by Ostenfeld (1908) and later by Iizumi et al. (1980), who reported that eelgrass morphology may reflect the nutrient level of a specific bed, and related 2 Zostera marina morphotypes to the nature of the sediment they inhabited (mud or sand). For example, longer and narrower leaves, shoots and internodes and a reduction in shoot density and biomass have been proposed as the main responses to depth (light) gradients (Backman \& Barilotti 1976, Phillips \& Lewis 1983, Short et al. 1995, Lee \& Dunton 1997, Hemminga \& Duarte 2000). These responses have been explained as a mechanism to reduce selfshading and the respiratory costs of below-ground biomass, and to increase the proportion of photosynthetic biomass. Morphological differences were also recorded in seagrasses plants living on different substrates, with muddy sediments producing plants with longer and wider leaves, but reduced development of the root-system and shoot densities than sandy sediments (Short 1983, 1987). Both responses, at the morphological and population levels, were related to the nitrogen pool in the sediment. Therefore, seagrass responses at different organisation levels (i.e. modules, individuals and/or populations) may differ depending on the forcing functions. However, none of the studies cited above addressed the organisation level at which the response took place, if other morphological and population responses are likely, or if these specific responses are predictable. Understanding the factors involved in plant morphology and population attributes will assist development of functional-structural seagrass models (FSSMs) as a management tool in restoration programmes and improve our understanding of seagrass ecosystems. The addition of morphological traits to existing space-explicit seagrass models (Marbá \& Duarte 1998, Sintes et al. 2005) will permit the simulation of phylloclimate variables (e.g. light, temperature, nutrients, hydrodynamic characteristics, etc.) allowing the inclusion of feedback mechanisms in morphological and architectural features, and accounting for the heterogeneity in biotic and abiotic factors usually recorded in seagrass meadows (Duarte \& Sand-Jensen 1990, Pedersen et al. 1997, Koch 2001, Brun et al. 2003a). Characterising phylloclimate variables using experiments or modelling raises questions about: (1) the response of individual shoots (and ultimately the seagrass populations) to heterogeneous environments, (2) the choice by the modules (and 
ultimately whole plant) of suitable space for clonal growth, and (3) the ability to individualise plant organs within a canopy. In this way, light, one of the major environmental factors affecting seagrass growth (Hemminga \& Duarte 2000), can be accurately estimated using canopy morphological features, shoot density and classical physical laws (Zimmerman 2003), which ultimately determine the light environment within a canopy and, therefore, photosynthesis and productivity. Studies on phylloclimate variables (nutrients, temperature, hydrodynamics, etc.) are still rare, precluding the development of complex FSSMs.

The main questions addressed in the present study were: (1) Can morphology and architecture at the whole-plant level be determined exclusively by a set of simple growth rules operating at the module level? (2) Can intra- and interspecific differences in plant dynamic parameters describe the morphological diversity and, consequently, species-specific attributes at the meadow level? (3) Are simple growth rules modulated by the surrounding environment, thus enabling the phylloclimate to be incorporated into FSSMs?

To check these hypotheses, seagrass plants were defined as a set of individual modules, and a deterministic individual-based model using the simplest set of growth rules was employed to simulate the growth of the modules of 2 seagrass species (Zostera noltii and Cymodocea nodosa). Both species were selected because they thrive in Cadiz Bay and there is a large data set available (Peralta et al. 2000, 2002, 2003, 2005, 2006, Brun et al. 2002, 2003a,b,c, 2005, 2006, unpubl.). In addition, detailed data on their growth patterns are available (Tomlinson 1974, 1982, Brun 2004, 2006) and both species have considerable architectural plasticity (Duarte 1991, Peralta et al. 2000, 2005, Brun et al. 2003a, 2005). Finally, we conducted a literature review on main environmental factors affecting the dynamic parameters of growth and meadow attributes to examine the possible use of the phylloclimate in developing FSSMs.

\section{MATERIALS AND METHODS}

Zostera noltii and Cymodocea nodosa architectural features. Zostera noltii Hornem. and Cymodocea nodosa Aschers. differ in module size and growth dynamics. The former displays a typical clonal structure with plagiotropic (i.e. horizontal) rhizomes bearing shoots and roots at every node and displaying high branching frequency, whereas the latter shows larger plagiotropic and orthotropic (i.e vertical) rhizomes bearing shoots at an indeterminate number of nodes and 1 root in each node. $Z$. noltii is considered as a pioneer and fast-growing species in comparison to $C$. nodosa (see den Hartog 1970, Tomlinson 1974 and Duarte 1991 for further information).

In a first approach, shoots can be grouped into apical (or runners) and non-apical (vertical shoots of Cymodocea nodosa are included in this category) (Tomlinson 1974, Brun et al. 2003a, 2006). All shoots are comprised of a variable number ( 2 to 5 ) of leaves, the youngest growing underneath the leaf sheath of the oldest, as in many monocots (Bell 1991). Leaves can be numbered according to age, from Leaf 1 (oldest leaf) to Leaf 5 (youngest leaf). Leaf No. 5 (L-5) is unique in that it is the first leaf of the bud primordium, growing beneath the sheath of the oldest leaf (L-1), and developing into L-1 in the new non-apical shoot generated from the apical shoot (Brun et al. 2006). Therefore, L-5 is not considered part of the apical shoot, and develops later than L-3. Rhizome growth and shoot recruitment depend on apical shoot activity (apical plastochrone interval). At each apical plastochrone interval, the apical shoot leaves the L- 1 and L- 5 in every node (that will generate a non-apical shoot). The release of new shoots will depend on the balance among apical (PI-A), non-apical (PI-L) and L-5 (PI-5) plastochrone intervals (Brun 2004, Brun et al. 2003a, 2006); see subsection 'Plant analysis' below.

Data acquisition. Data for Zostera noltii were obtained from temporal field sampling programmes and plants collected for experimental purposes (Peralta et al. 2000, 2002, 2003, 2005, 2006, Brun 2004, Brun et al. 2002, 2003a,b,c, 2005, 2006 and unpubl. data). Data for Cymodocea nodosa were obtained from temporal field samplings ( 3 consecutive years) in Cádiz Bay Natural Park and from plants taken for experimental purposes (García-Sánchez et al. unpubl. data). Summarising, the pool of data comprised field and experimental records from several locations (Cádiz Bay Natural Park and Palmones river estuary, southern Spain; Ria Formosa Natural Park, southern Portugal; Zandkreek, a mudflat in the Oosterschelde Estuary, The Netherlands), all seasons, different years (from 1997 to 2005) and annual ( $Z$. noltii in the Dutch littoral) and perennial (southern locations) populations.

Plant analysis. Mean shoot-leaf length (MSL) was computed as the sum of the leaf lengths in a shoot divided by the number of leaves in the shoot. Both sheath and blade were included to calculate the total leaf length (hereafter 'leaf length'). In Zostera noltii, only unbroken leaves were used to estimate the leaf length (percentage broken leaves $<5 \%$ ), while in Cymodocea nodosa a high percentage $(>80 \%$ ) of the oldest leaves were broken, and were included as such in the calculations. Leaf, shoot and rhizome elongation rates (LER, SER and RER, respectively) were estimated according to a modification of the punching method (Peralta et al. 2000). All leaves within the shoot were measured 
allowing the estimation of individual leaf-elongation rates (LER, $\left.\mathrm{cm} \mathrm{d}^{-1}\right)$. SER was computed as the sum of LER within a shoot. Since rhizome elongation proceeds from the apical shoot, punching this type of shoot allowed the estimation of RER. Sorting apical shoots for punching within $Z$. noltii beds was fairly straightforward. In contrast, only some apical shoots were sporadically marked in C. nodosa beds, precluding RER estimations. In this case, data from Marbá \& Duarte (1998) were used. Leaf width and thickness were estimated for the oldest leaves (L-1 and L-2). Rhizome internode length and cross-section were only measured in horizontal rhizomes that were completely developed. Leafarea index (LAI) was determined by multiplying the mean surface area of shoots (1 face only) by shoot density. Above-ground and below-ground biomasses and individual shoot weight were estimated by oven-drying $\left(60^{\circ} \mathrm{C}\right)$ the samples to a constant weight. We considered 3 different plastochrone intervals: the apical plastochrone interval (PI-A), calculated for L-1 to L-4 of the apical shoots; the non-apical plastochrone interval (PIL), calculated for L-1 to L-4 of the non-apical shoots; and the plastochrone interval for L-5 (PI-5), computed as the time interval between the production of 2 successive L-5s (Tables $1 \& 2$ ). The term PI alone is used to refer to PI-A, PI-L or PI-5 when these are not distinguished in the equations (see Peralta et al. 2000, Brun et al. 2003a, 2006 for additional information). The degree of intraspecific plasticity in architectural traits, dynamic parameters and meadow attributes were quantified as the coefficient of variation $(\mathrm{CV})$ of the data, as described by other authors (Duarte 1991, Hemminga \& Duarte 2000).

Model design. The architectural features and meadow attributes of Zostera noltii and Cymodocea nodosa were investigated using a deterministic, individual-based, numerical model. Essentially, the model is based on the hypothesis that plant morphology is determined by simple growth rules and dynamic growth parameters (PI, LER, RER) acting at the module level. The re-iteration of the module morphology (internode, node and shoot) will determine individual plant architecture and ultimately meadow properties. Shoot development is considered a continuous process that can be simulated through discrete steps. The oldest leaf (L-1) is the final stage of the 'leaf history'. Thus, initially (Time $=0$ ), L-1 is in fact the youngest leaf (L-4); 1 PI later, a new leaf appears, moving L-4 to the third position within the shoot, whereby it becomes L-3. In a further PI step, L-3 is shifted to the second position (L-2) within the shoot, and 1 PI later is the oldest leaf, L-1. At each step, the leaf grows at its own elongation rate $\left(\mathrm{LER}_{\mathrm{n}}\right.$, where $\mathrm{n}$ is leaf number), which is age-dependent (the younger the leaf, the faster the growth: see Tables 3 \& 4). Using this step-wise approach, leaf length at each step (from L-1 to L-4) can be estimated by LER and PI. The sum of all 4 lengths gives the final (i.e. accumulated) leaf length $\left(L L_{\mathrm{n}}\right)$ :

$$
\mathrm{LL}_{n}=\sum_{i=0}^{4-n} \mathrm{LER}_{n+i} \cdot \mathrm{PI}
$$

The final length of L-5 ( $\left.\mathrm{LL}_{5}\right)$ is calculated using PI-5 and the leaf-elongation rate for this leaf $\left(\mathrm{LER}_{5}\right)$ as

$$
\mathrm{LL}_{5}=\mathrm{LER}_{5} \cdot \mathrm{PI}-5
$$

Rhizome elongation occurs during 1 apical PI (PI-A) step. Consequently, internode length (IL) can be estimated from PI-A and rhizome elongation rate (RER) as

$$
\mathrm{IL}=\mathrm{RER} \cdot \mathrm{PI}-\mathrm{A}
$$

Sheath length (ShL) for the oldest leaf (L-1) was estimated using the average ratio in Tables 3 \& 4 between leaf and sheath length $(22.8 \pm 0.18$ and $33.9 \pm 0.9 \%$ for Zostera noltii and Cymodocea nodosa respectively):

\begin{tabular}{|c|c|c|}
\hline $\begin{array}{l}\text { Parameter/ } \\
\text { variable }\end{array}$ & Description & Unit \\
\hline $\mathrm{T}_{j}$ & Absolute time in PI No. j. & d \\
\hline PI & Plastochrone interval & $\mathrm{d}$ \\
\hline PI-A & Plastochrone interval for apical shoots & $\mathrm{d}$ \\
\hline PI-L & Plastochrone interval for non-apical shoots & $\mathrm{d}$ \\
\hline PI-5 & Plastochrone interval for L-5 & d \\
\hline $\mathrm{PI}_{j}\left(\mathrm{~T}_{j}\right)$ & Plastochrone interval at Time $j$ & $\mathrm{~d}$ \\
\hline $\mathrm{LER}_{\mathrm{n}}$ & Leaf-elongation rate of Leaf No. $\mathrm{n}$ & $\mathrm{cm} \mathrm{d}^{-1}$ \\
\hline $\operatorname{LER}_{\mathrm{n}}^{j}\left(\mathrm{~T}_{j}\right)$ & Leaf-elongation rate of Leaf No. $\mathrm{n}$ in the Time $j$ & $\mathrm{~cm} \mathrm{~d}^{-1}$ \\
\hline RER & Rhizome elongation rate & $\mathrm{cm} \mathrm{d}^{-1}$ \\
\hline $\mathrm{RER}_{j}\left(\mathrm{~T}_{j}\right)$ & Rhizome elongation rate in the time $j$ & $\mathrm{~cm} \mathrm{~d}^{-1}$ \\
\hline $\mathrm{TLL}_{\mathrm{n}}$ & Total leaf length of Leaf No. $\mathrm{n}$ & $\mathrm{cm}$ \\
\hline $\mathrm{TLL}_{5}$ & Total leaf length of Leaf No. 5 & $\mathrm{~cm}$ \\
\hline $\mathrm{IL}_{j}$ & Internode length at Time $j$ & $\mathrm{~cm}$ \\
\hline SER & $\begin{array}{l}\text { Shoot-elongation rate, calculated as sum of } \\
\text { all leaf-elongation rates }\end{array}$ & cm shoot $d^{-1}$ \\
\hline Density & $\begin{array}{l}\text { Shoot density calculated from linear } \\
\text { rhizome growth within } 1 \mathrm{~m}^{2} \text { reference area, } \\
\text { presumed initial density of } 100 \text { shoots } \mathrm{m}^{-2}\end{array}$ & shoots $\mathrm{m}^{-2}$ \\
\hline SW & Shoot weight & mg dry wt shoot ${ }^{-1}$ \\
\hline LAI & Leaf area index (1 leaf side) & $\mathrm{m}^{2} \mathrm{~m}^{-2}$ \\
\hline $\mathrm{AB}: \mathrm{BB}$ & Above:below-ground biomass ratio & - \\
\hline LDW & Leaf dry weight & $\mathrm{g} \mathrm{m}^{-2}$ \\
\hline LA & Leaf area & $\mathrm{cm}^{-2}$ \\
\hline RDW & Rhizome dry weight & $\mathrm{g} \mathrm{m}^{-2}$ \\
\hline RL & Rhizome length & $\mathrm{cm}$ \\
\hline
\end{tabular}

Table 1. Symbols and units of parameters and variables used in model. Further details in 'Materials and methods' 


$$
\mathrm{ShL}=\mathrm{LL}_{l} \cdot 0.228(\text { or } 0.339)
$$

Sheath length was added to leaf length, giving the total leaf length

$$
\mathrm{TLL}_{\mathrm{n}}=\mathrm{LL}_{\mathrm{n}}+\mathrm{ShL}
$$

Although leaf width displayed very low variability, a highly significant correlation between LW and the SER:PI ratio ( $\mathrm{r}=0.78, \mathrm{p}<0.0001, \mathrm{n}=109$; Eq. 6$)$ was found for Zostera noltii:

$$
\text { Leaf width }=0.918+0.584 \cdot\left(\frac{\mathrm{SER}}{\mathrm{PI}}\right)
$$

Hence, the plasticity in leaf width for the seagrass $Z$. noltii was also included in the model.

By this discrete, step-wise approach, the leaf and rhizome lengths can be estimated using either constants (Eqs. 1, 2, 3, 4 \& 5) or time-dependent PI, LER and RER values (see relevant symbols and Eqs. 7 to 14 in Tables 1 \& 2).

Shoot density was estimated from internode length assuming linear expansion of the clone network (i.e. the model does not consider branching), the percentage of nodes bearing shoots ( 1 and 0.5 for Zostera noltii and Cymodocea nodosa respectively; Duarte 1991 \& Brun unpubl. data) and an initial apical shoot density of 100 plants $\mathrm{m}^{-2}$ (mean lowest shoot density for both species). Leaf-area index (LAI) was calculated for 1 leaf side. Total light reaching the bottom of the seagrass canopy was computed using a surface irradiance of $2500 \mu \mathrm{mol}$ photons $\mathrm{m}^{-2} \mathrm{~s}^{-1}$ and the relationship between LAI and light-attenuation coefficient given in Pérez-Lloréns \& Niell (1991). Leaf-area (LA):dry wt (LDW) and rhizome length (RL):dry wt (RDW) ratios were calculated by pooling the available field and laboratory data. Above-ground:below-ground biomass ratio was calculated from total rhizome length, leaf area, length:weight and area:weight relationships. Shoot weight was estimated by calculating the leaf area within a shoot and multiplying it by the LA:LDW ratio. For simplicity, the plastochrone intervals PI-A, PI-L and PI-5 were considered to have the same value.

The model was constructed to simulate the observed interspecific variability in plant and meadow properties using the natural range of variability in the dynamic parameters for the species investigated. Thus, simulations emulated the observed variability in the plant dynamic parameters (100 and 75\%, for Zostera noltii and Cymodocea nodosa respectively; Tables 3 \& 4), using 3 different input values (or scenarios) for each species. For $Z$. noltii the scenarios were 'normal' dynamic parameter values ([1-PI], [1-LER], [1-RER]); 'double' ([2-PI], [2-LER], [2-RER]); and 'half' ([PI/2], [LER/2], [RER/2]). For C. nodosa they were 'normal' ([1·PI], [1-LER], [1·RER]); an increment of $50 \%$ ([1.5·PI],
Table 2. Model equations for leaf and rhizome lengths using time-dependent elongation rates (leaf and rhizome) and plastochrone intervals (apical, non-apical and L-5). Abbreviations as in Table 1

\begin{tabular}{l} 
Equation \\
\hline $\mathrm{PI}_{0}=0$ \\
$\mathrm{~T}_{j}=t+\sum_{i=1}^{j} \mathrm{PI}_{\mathrm{i}-1}$ \\
$\mathrm{PI}_{0}=\mathrm{PI}\left(\mathrm{T}_{j}\right)$ \\
$\mathrm{LER}_{n}^{j}=\mathrm{LER}_{n}\left(\mathrm{~T}_{j}\right)$ \\
$\mathrm{RER}_{j}=\mathrm{RER}\left(\mathrm{T}_{j}\right)$ \\
$\mathrm{TLL}_{n}=\sum_{i=0}^{4-n} \mathrm{LER}_{4-n}^{j+1} \cdot \mathrm{PI}_{j+i}$ \\
$\mathrm{TLL}_{5}=\mathrm{LER}_{5}^{3} \cdot \mathrm{PI}_{-5} 5_{3}$ \\
$\mathrm{TIL}_{j}=\mathrm{RER}_{j} \cdot \mathrm{PI}-\mathrm{A}_{j}$
\end{tabular}

[1.5·LER], [1.5·RER]); and a decrement of $33 \%$ ([PI/1.5], [LER/1.5], [RER/1.5]). The 'normal' values used for the input parameters (PI, LER, RER) were the mean values in Tables 3 \& 4. For each scenario, the model was also simulated for 4 different conditions (i.e shoots with 2, 3, 4 or 5 leaves), in accordance with the observed (i.e. natural) variability range in the number of standing leaves within the shoots. Accordingly, the total number of simulations for each variable was 108 (27 scenarios $\times$ 4 conditions). The model was constructed using Stella Research 7.0 software (isee ${ }^{\mathrm{TM}}$ systems), with space implicit and all shoots considered equivalent. Initial values (time, $t=0$ ) for each outcome variable were zero, except for shoot density (100 shoots $\left.\mathrm{m}^{-2}\right)$. Simulations were run with a $\Delta t$ of $1 \mathrm{~d}$, until a steady state was reached for all the variables assayed.

A Student's $t$-test for unpaired data with unequal variance was used to reveal differences in morphological, dynamic and meadow properties among seagrass species in the observed and predicted data. Data were log-transformed where necessary to comply with homocedasticity and normality of the data. Linear correlation was used to test the reliability of the observed versus predicted data. The significance level was set at $5 \%$ in all cases.

\section{RESULTS}

Tables 3 \& 4 show empirical data on morphometric, dynamic and meadow properties for Zostera noltii and Cymodocea nodosa. A similar plasticity (i.e. variability) was recorded in both species, although the variability 
Table 3. Zostera noltii. Observed and simulated architectural, dynamic and meadow properties. Observed data are from field campaigns and experiments (see 'Materials and methods; Model design' for further details), simulated data obtained by pooling results of all simulated conditions $(\mathrm{n}=108)$. Asterisks next to 'Simulated mean' indicate significant differences between observed and simulated data; asterisks next to 'No. of observations' indicate between-species differences; ${ }^{*} \mathrm{p}<0.05 ;{ }^{* *} \mathrm{p}<0.01$; ${ }^{* * *} \mathrm{p}<$ 0.001; ns: not significant. DW: dry wt; other abbreviations as in Table 1

\begin{tabular}{|c|c|c|c|c|c|c|}
\hline \multirow[t]{2}{*}{ Parameter } & \multicolumn{2}{|c|}{ Range } & \multicolumn{2}{|c|}{ Mean \pm SE } & \multirow[t]{2}{*}{ CV (\%) } & \multirow[t]{2}{*}{ No. obs. } \\
\hline & $\begin{array}{c}\text { Observed } \\
(\min -\max )\end{array}$ & $\begin{array}{c}\text { Simulated } \\
(\min -\max )\end{array}$ & Observed & Simulated & & \\
\hline \multicolumn{7}{|l|}{ Architectural traits } \\
\hline Mean shoot length $(\mathrm{cm})$ & $(3.5-35.3)$ & $(1.9-39)$ & $10.8 \pm 0.31$ & $11.9 \pm 0.9^{* * *}$ & 58 & $1537^{* * *}$ \\
\hline \multicolumn{7}{|l|}{ Leaf length $(\mathrm{cm})$} \\
\hline L-1 & $(2.7-49)$ & $(2.6-41.1)$ & $14.2 \pm 0.20$ & $13.9 \pm 1.1^{* * *}$ & 56 & $1664^{* * *}$ \\
\hline L-2 & $(2.7-45.8)$ & $(2.3-37.3)$ & $15.8 \pm 0.21$ & $12.6 \pm 0.9^{* * *}$ & 53 & $1660^{* * *}$ \\
\hline L-3 & $(2.2-39.2)$ & $(2-32.1)$ & $11.2 \pm 0.20$ & $10.9 \pm 0.8^{* * *}$ & 64 & $1419^{* * *}$ \\
\hline L-4 & $(1.4-26.1)$ & $(1.5-23.3)$ & $4.9 \pm 0.14$ & $7.9 \pm 0.6^{* * *}$ & 78 & $743^{* * *}$ \\
\hline L-5 & $(1.4-17.3)$ & $(1.4-21.7)$ & $4.7 \pm 0.21$ & $7.4 \pm 0.6^{* * *}$ & 70 & $485^{* * *}$ \\
\hline Sheath length $(\mathrm{cm})$ & $(0.8-10.5)$ & $(0.47-9.3)$ & $3.9 \pm 0.05$ & $3.0 \pm 0.2^{* * *}$ & 52 & $1416^{* * *}$ \\
\hline$\%$ sheath vs blade & $(8-70)$ & & $22.8 \pm 0.18$ & & 35 & $1987^{* * *}$ \\
\hline Leaf width (mm) & $(0.6-2.1)$ & $(0.94-1.35)$ & $1.18 \pm 0.006$ & $1.07 \pm 0.11$ & 19 & $1443^{* * *}$ \\
\hline Leaf thickness (mm) & $(0.09-0.21)$ & - & $0.155 \pm 0.001$ & - & 16 & $614^{* * *}$ \\
\hline Leaf abundance (leaves shoot-1) & $(2-5)$ & - & $3.2 \pm 0.06$ & - & 29 & $1245 \mathrm{~ns}$ \\
\hline Shoot weight (mg DW shoot-1) & $(3.7-41)$ & $(2.0-65.2)$ & $14.3 \pm 0.8$ & $17.5 \pm 1.4^{* * *}$ & 56 & $305^{* * *}$ \\
\hline Internode length (cm) & $(0.1-6.0)$ & $(0.3-4.8)$ & $1.3 \pm 0.03$ & $1.6 \pm 0.13^{* * *}$ & 65 & $554^{* * *}$ \\
\hline Rhizome section (mm2) & $(0.36-4.5)$ & - & $0.98 \pm 0.02$ & - & 47 & $356^{* * *}$ \\
\hline Mean architectural $\mathrm{CV} \pm \mathrm{SE}$ & & & $51 \pm 5.3$ & $82 \pm 0.7$ & & \\
\hline \multicolumn{7}{|l|}{ Dynamic features } \\
\hline SER (cm d-1 plant-1) & $(0.088-5.53)$ & - & $1.48 \pm 0.05$ & - & 69 & $411^{*}$ \\
\hline L-1 & $(0-1.46)$ & - & $0.12 \pm 0.008$ & - & 213 & $1100 \mathrm{~ns}$ \\
\hline L-2 & $(0-1.52)$ & - & $0.15 \pm 0.006$ & - & 151 & $1189^{* * *}$ \\
\hline L-3 & $(0-1.7)$ & - & $0.28 \pm 0.01$ & - & 108 & $1035^{* * *}$ \\
\hline L-4 & $(0.11-1.89)$ & - & $0.49 \pm 0.01$ & - & 65 & $959^{* * *}$ \\
\hline L-5 & $(0.11-1.52)$ & - & $0.44 \pm 0.01$ & - & 62 & $907^{* * *}$ \\
\hline RER (cm d-1 plant-1) & $(0.013-1.2)$ & - & $0.15 \pm 0.008$ & - & 79 & 581 \\
\hline $\mathrm{PI}(\mathrm{d})$ & $(0.8-29.4)$ & - & $8.3 \pm 0.67$ & - & 50 & $959^{* * *}$ \\
\hline Mean dynamic $\mathrm{CV} \pm \mathrm{SE}$ & & & $100 \pm 20$ & & & \\
\hline \multicolumn{7}{|l|}{ Meadow properties } \\
\hline Density (shoots m-2) & $(95-18175)$ & $(2083-33333)$ & $4945 \pm 259$ & $11342 \pm 886^{* * *}$ & 64 & $147^{* * *}$ \\
\hline Above-ground biomass (g DW $\mathrm{m}-2$ ) & $(2-207)$ & $(17.3-715)$ & $65.6 \pm 4.4$ & $151 \pm 14^{* * *}$ & 70 & $137^{* * *}$ \\
\hline Below-ground biomass (g DW m-2) & $(1.4-305)$ & $(35.7-35.7)$ & $58.3 \pm 5.1$ & $35.7 \pm 0^{* * *}$ & 102 & $135^{* * *}$ \\
\hline Above:below-ground ratio & $(0.11-14.2)$ & $(0.48-20)$ & $2.0 \pm 0.17$ & $4.2 \pm 0.38^{* * *}$ & 97 & $134^{* * *}$ \\
\hline LAI (m2 m-2) & $(0.12-5.9)$ & $(0.47-17.4)$ & $1.9 \pm 0.11$ & $(3.7 \pm 0.33)^{* * *}$ & 68 & $137^{* * *}$ \\
\hline Mean meadow $\mathrm{CV} \pm \mathrm{SE}$ & & & $80 \pm 8$ & $87 \pm 3$ & & \\
\hline
\end{tabular}

in the dynamic parameters and in meadow attributes was slightly higher in Z. noltii (Tables 3 \& 4). As expected, $C$. nodosa had significantly longer and wider leaves, sheaths and rhizome internodes and, therefore, heavier shoots than $Z$. noltii (Tables 3 \& 4). Furthermore, shoot-elongation rate (SER), leaf-elongation rates $\left(\mathrm{LER}_{\mathrm{n}}\right)$ and plastochrone interval (PI) were significantly higher for $C$. nodosa than for $Z$. noltii. The meadow properties differed significantly between the 2 species, with a lower shoot density and above:belowground ratio in C. nodosa. This contrasts with the higher biomass recorded for this species (Tables 3 \& 4). Variability in architectural and meadow attributes in both species was lower than that for dynamic parameters in both species $(100 \pm 20$ and $77 \pm 8 \%$ for dynamic parameters for $Z$. noltii and C. nodosa respectively) (Tables 3 \& 4). Among the architectural parameters, the lowest variability was found for thickness, width, and number of standing leaves (CV $=16,19$ and $29 \%$ for Z. noltii and 38, 24, $25 \%$ for C. nodosa). Variability in meadow properties ranged from 44 to $102 \%$, belowground biomass being the attribute with the highest interspecific difference (Tables $3 \& 4$ ).

\section{Model outputs}

Only results for Zostera noltii plants bearing shoots with 5 leaves are depicted graphically, although all simulated data in for both species are included in the 
Table 4. Cymodocea nodosa. Observed and simulated architectural, dynamic and meadow properties. Observed data from field campaigns and experiments (see 'Materials and methods' for further details), simulated data obtained by pooling results of all simulated conditions $(n=108)$ DW: dry wt; other abbreviations as in Table 1

\begin{tabular}{|c|c|c|c|c|c|c|}
\hline \multirow[t]{2}{*}{ Parameter } & \multicolumn{2}{|c|}{ Range } & \multicolumn{2}{|c|}{ Mean \pm SE } & \multirow[t]{2}{*}{ CV $(\%)$} & \multirow[t]{2}{*}{ No. obs. } \\
\hline & $\begin{array}{l}\text { Observed } \\
\text { (min-max) }\end{array}$ & $\begin{array}{c}\text { Simulated } \\
(\min -\max )\end{array}$ & Observed & Simulated & & \\
\hline \multicolumn{7}{|l|}{ Architectural traits } \\
\hline Mean shoot length $(\mathrm{cm})$ & $(5.5-98)$ & $(14.5-99)$ & $34.6 \pm 0.7$ & $42.7 \pm 2.0$ & 51 & 601 \\
\hline L-1 & $(6-135)$ & $(19-101)$ & $37.5 \pm 0.92$ & $50 \pm 2.2$ & 56 & 526 \\
\hline $\mathrm{L}-2$ & $(5-101)$ & $(18.5-96)$ & $41.2 \pm 0.91$ & $47 \pm 2.1$ & 59 & 585 \\
\hline L-3 & $(2.7-98)$ & $(15-77.4)$ & $35.4 \pm 0.93$ & $38.2 \pm 1.8$ & 65 & 516 \\
\hline L-4 & $(2-71.5)$ & $(10-52)$ & $22.3 \pm 0.86$ & $25.7 \pm 1.2$ & 81 & 266 \\
\hline L-5 & $(2.8-30.5)$ & $(9-46)$ & $13.5 \pm 1.4$ & $23 \pm 1.1$ & 87 & 38 \\
\hline Sheath length $(\mathrm{cm})$ & $(2.1-37)$ & $(3.6-19)$ & $10 \pm 0.2$ & $9.3 \pm 0.4$ & 47 & 485 \\
\hline$\%$ sheath vs. blade & $(12-90)$ & - & $33.9 \pm 0.9$ & - & 52 & 465 \\
\hline Leaf width (mm) & $(2-8.7)$ & - & $4.7 \pm 0.05$ & - & 24 & 575 \\
\hline Leaf thickness (mm) & $(7-45)$ & - & $22.6 \pm 0.5$ & - & 38 & 328 \\
\hline Leaf abundance (leaves shoot ${ }^{-1}$ ) & $(2-5)$ & - & $3.3 \pm 0.03$ & - & 25 & 597 \\
\hline Shoot weight (mg DW shoot ${ }^{-1}$ ) & $(16-1002)$ & $(68-662)$ & $315 \pm 30$ & $256 \pm 13$ & 80 & 272 \\
\hline Internode length (cm) & $(0.3-11.5)$ & $(1-5)$ & $2.1 \pm 0.1$ & $2.4 \pm 0.1$ & 89 & 445 \\
\hline Rhizome section $\left(\mathrm{mm}^{2}\right)$ & $(2-37.4)$ & - & $14.3 \pm 0.4$ & - & 48 & 322 \\
\hline Mean architectural $\mathrm{CV} \pm \mathrm{SE}$ & & & $57 \pm 6$ & $48 \pm 0.2$ & & \\
\hline \multicolumn{7}{|l|}{ Dynamic features } \\
\hline SER $\left(\mathrm{cm} \mathrm{d}^{-1}\right.$ plant $\left.^{-1}\right)$ & $(0.12-6.8)$ & - & $1.7 \pm 0.1$ & - & 78 & 164 \\
\hline L-1 & $(0-0.9)$ & - & $0.12 \pm 0.04$ & - & 107 & 30 \\
\hline $\mathrm{L}-2$ & $(0-1.5)$ & - & $0.41 \pm 0.04$ & - & 75 & 60 \\
\hline L-3 & $(0.03-1.9)$ & - & $0.56 \pm 0.04$ & - & 84 & 179 \\
\hline L-4 & $(0.06-2.9)$ & - & $0.74 \pm 0.04$ & - & 60 & 115 \\
\hline L-5 & $(0.13-2.6)$ & - & $0.62 \pm 0.04$ & - & 60 & 43 \\
\hline $\operatorname{RER}\left(\mathrm{cm} \mathrm{d}^{-1} \text { plant }^{-1}\right)^{\mathrm{a}}$ & $(0.01-0.6)$ & - & 0.11 & - & 107 & - \\
\hline PI $(d)$ & $(5.6-42)$ & - & $20.7 \pm 0.7$ & - & 43 & 146 \\
\hline Mean dynamic $\mathrm{CV} \pm \mathrm{SE}$ & & & $77 \pm 8$ & & & \\
\hline \multicolumn{7}{|l|}{ Meadow properties } \\
\hline Density (shoots m ${ }^{-2}$ ) & $(112-1556)$ & $(1010-5218)$ & $540 \pm 36$ & $2556 \pm 118$ & 56 & 72 \\
\hline Above-ground biomass (g DW m ${ }^{-2}$ ) & $(16-501)$ & $(158-1498)$ & $123 \pm 10$ & $584 \pm 30$ & 76 & 81 \\
\hline Below-ground biomass (g DW m ${ }^{-2}$ ) & $(25-489)$ & $(430-430)$ & $249 \pm 12$ & $430 \pm 0$ & 44 & 81 \\
\hline Above:below-ground ratio & $(0.1-2.1)$ & $(0.3-3.5)$ & $0.58 \pm 0.05$ & $1.3 \pm 0.07$ & 77 & 81 \\
\hline LAI $\left(\mathrm{m}^{2} \mathrm{~m}^{-2}\right)$ & $(0.5-14.2)$ & $(4.2-39)$ & $3.5 \pm 0.3$ & $15.4 \pm 0.5$ & 74 & 81 \\
\hline Mean meadow $\mathrm{CV} \pm \mathrm{SE}$ & & & $66 \pm 7$ & $51 \pm 1$ & & \\
\hline${ }^{a}$ From Marbá \& Duarte 1998 & & & & & & \\
\hline
\end{tabular}

calculations in Tables 3 \& 4. Fig. 1 shows the leaf lengths attained for the 9 feasible combinations of input parameters (however, only 5 different outputs were achieved because of the opposing effects of LER and PI on leaf length). The longest leaves (up to $40 \mathrm{~cm}$ for the oldest) were attained at [2.PI]\&[2-LER], and the shortest (ca. $2 \mathrm{~cm}$ ) at (i.e. [0.5·PI]\&[0.5 LER] (i.e. the opposite simulation conditions) (Fig. 1). There was a positive relationship between mean shoot length (MSL; range from 1.9 to $31 \mathrm{~cm}$ ) and LER and PI (Fig. 2A). The fewer the number of leaves, the longer the MSL (the longest MSL was $39 \mathrm{~cm}$ in shoots with 2 standing leaves; data not shown). Overall, leaf width was correlated negatively with PI and positively with LER $(0.94 \mathrm{~mm}$ at [2.PI]\&[0.5.LER] and $1.35 \mathrm{~mm}$ at [0.5.PI]\&[2-LER] (Fig. 2B). The heaviest shoots were also the longest (i.e. under [2.PI] \& [2-LER]) when grown at low densities (Fig. 2C). As for MSL, internode length (range 0.3 to $4.8 \mathrm{~cm}$ ) was positively related with RER and PI (Fig. 2D). The opposite trend was observed for shoot density, with values ranging from 33333 shoots $\mathrm{m}^{-2}$ (at $[0.5 \cdot \mathrm{PI}] \&[0.5 \cdot \mathrm{RER}]$, coinciding with the lowest MSLs) to 2100 shoots $\mathrm{m}^{-2}$ (at [2·PI]\&[2-RER] and coinciding the highest MSLs) (Fig. 2E). The results for leaf-area index (LAI) were somewhat unexpected, since they were fairly PI-independent (Fig. 2F). Increases or decreases in shoot density and/or MSL resulted in comparable LAI values (Fig. 2F). The highest values (ca. 17) were recorded at [0.5 RER]\&[2.LER] and the lowest (ca. 1) at [2·RER]\&[0.5-LER] (i.e. the opposite simulation conditions). A drop in LAI (range 7.6 to 0.48 ) was observed when the number of standing 


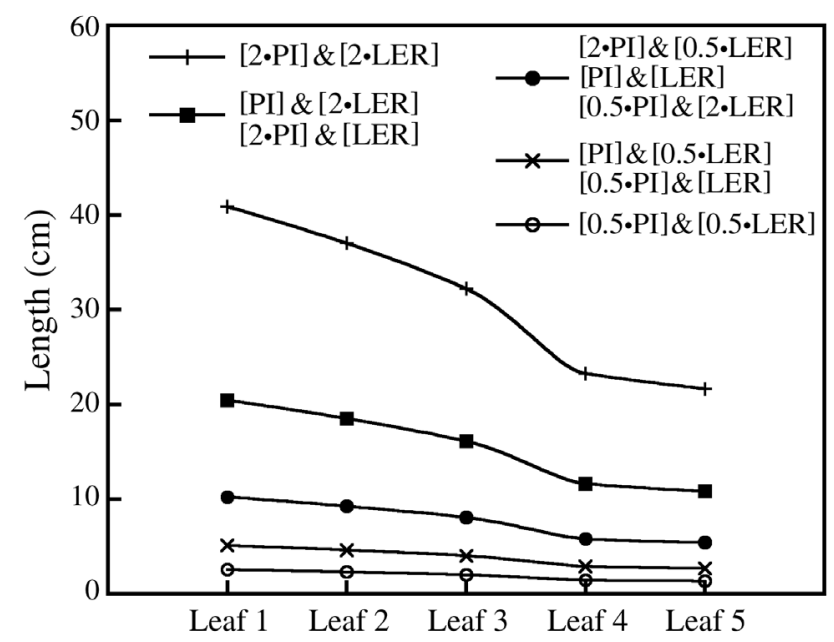

Fig. 1. Zostera noltii. Simulated within-shoot leaf-length distribution. Simulations doubled (2.) the normal value of the parameters and/or used half (0.5•) normal values. See 'Materials and methods; Model design' for further details. PI: plastochrone interval; LER: leaf-elongation rate. Simulations were run until steady state was reached

leaves per shoot decreased (data not shown). The highest PFD underneath the canopy $(\sim 1700 \mu$ mol photons $\mathrm{m}^{-2} \mathrm{~s}^{-1}$ ) was recorded for low shoot densities and shortsized shoots. Overall, the lowest PFD (at [0.5·RER]\&[2-LER]) was achieved under high shoot densities and MSLs. Clearly, a reduction in the number of leaves resulted in higher PFDs under the canopy (data not shown). No positive correlations were found for above:below-ground biomass ratio ( $\mathrm{AB}: \mathrm{BB}$ ratio) and shoot density, internodal length or MSL. The $\mathrm{AB}: \mathrm{BB}$ ratio followed a similar pattern to that previously described for LAI, ranging around 20 (at $[0.5 \cdot \mathrm{RER}] \&[2 \cdot \mathrm{LER}])$ and $1([2 \cdot \mathrm{RER}] \&[0.5 \cdot \mathrm{LER}])$ (data not shown).

The range and average data for simulated and measured plant architectural and meadow properties for both species are shown in Tables $3 \& 4$. The percentage of broken leaves in Cymodocea nodosa would largely explain the differences between simulated (i.e. potential lengths in absence of breakage) and measured leaf lengths, especially in the oldest leaves (1 and 2). A high significant correlation was recorded ( $\mathrm{p}<$ 0.0001, $r=0.99, \mathrm{~N}=19$; Fig. 3) between predicted versus observed plant architectural features for both species, indicating that this individual-based model was able to simulate natural variability in architectural properties using the variability recorded in plant dynamic parameters. Predicted meadow attributes were, on average, 2-fold higher than those observed for intraspecific observations. This can be mainly attributed to the absence of density-dependence impediments or loss mechanisms (Tables 3 \& 4). How- ever, interspecific differences in meadow properties were achieved. The model predicted a lower aboveand below-ground biomass, lower LAI, and a higher shoot density in Zostera noltii than in C. nodosa (Tables 3 \& 4), in agreement with experimental observations. Simulated below-ground biomass did not display any variability, since all calculations were for the same reference area $\left(1 \mathrm{~m}^{2}\right)$ and presumed rhizomatic linear expansion (i.e. no secondary branches).

The model shows that the combination of the different input parameters yielded a high variability of responses in the variables analysed. Quantitative knowledge of the spatially-explicit relationship between plant dynamic parameters and environmental conditions is essential for predicting responses at module, plant and meadow levels wiht regard to phylloclimate. Table 5 presents an overview of literature on plant dynamic parameters, shoot morphology and meadow properties related with the main environmental factors (light, nutrients and hydrodynamic characteristics) gained from field observations and manipulative experiments. Although temperature is considered one of the main external forcing variables both in land plants and in seagrasses (Bos \& Neuteboom 1998, Hemminga \& Duarte 2000), in the latter it has been mainly related to photosynthetic activity (PérezLloréns \& Niell 1993, Masini \& Manning 1997, Seddon \& Cheshire 2001) or correlated with field observations (Touchette \& Burkholder 2002, Kentula \& Dewitt 2003), with studies on its direct effect on seagrasses being, as far as we are aware, lacking. Dynamic parameters were rarely recorded in the studies listed in Table 5. While plastochrone intervals and rhizome-elongation rates were recorded in only $25 \%$ of the studies, leafelongation rates were recorded in $62 \%$ (Table 5). However, whole-plant dynamic parameters, shoot morphology and meadow properties were recorded simultaneously in only 2 studies (Bintz \& Nixon 2001, Peralta et al. 2005). Studies on light reduction revealed regularity in the effects on dynamic parameters. A large fraction of these studies reported an increase in the PI and a reduction in growth rates (leaf and rhizome) (Table 5). Shoot morphology showed high variability in the light-reduction treatments, with no clear tendencies (Table 5). In contrast, a reduction in meadow properties (density and biomass-total, aboveand below-ground) was commonly recorded (Table 5).

Nutrient addition enhanced growth rates (leaves and rhizomes) as well as leaf length, biomass and shoot densities (Table 5). However, the effects depended on species (Powell et al. 1989, Terrados et al. 1999), nutrient supplied (Short 1987, Brun et al. 2002), nutrient concentration (Brun et al. 2002, Peralta et al. 2003), season (Alcoverro et al. 1997), sediment type (Short 1983) and temperature (van Katwijk et al. 1997). Nutri- 

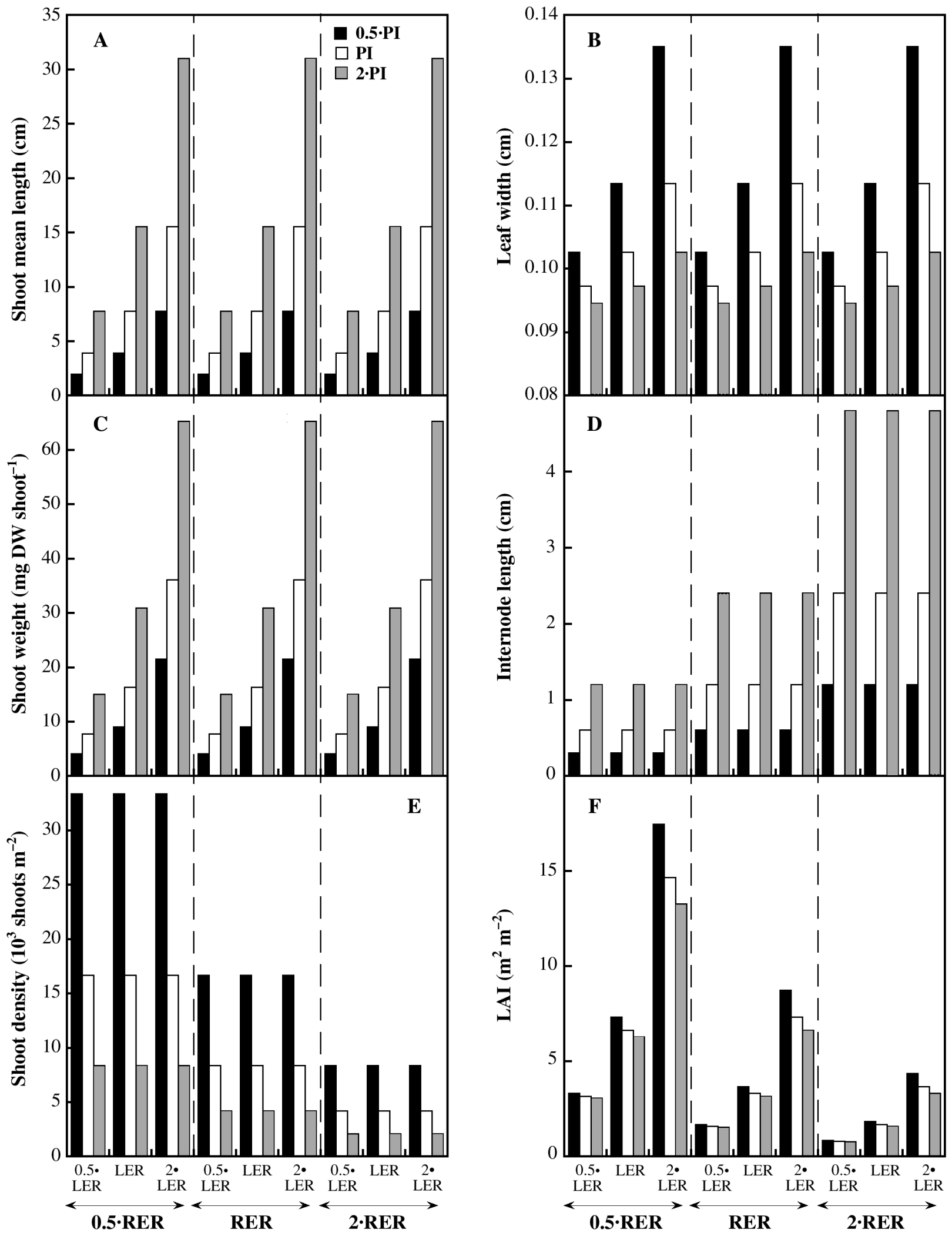

Fig. 2. Zostera noltii. Predicted values for mean shoot (A) leaf length, (B) leaf width, (C) weight, (D) internode length, (E) density and (F) leaf-area index (LAI). Results obtained simulating normal dynamic parameter values, double (2·) the normal value of the parameters, and half $(0.5 \cdot)$ normal values. PI: plastochrone interval; LER: leaf elongation rate; RER: rhizome elongation rate. Simulations were run until steady state was reached 


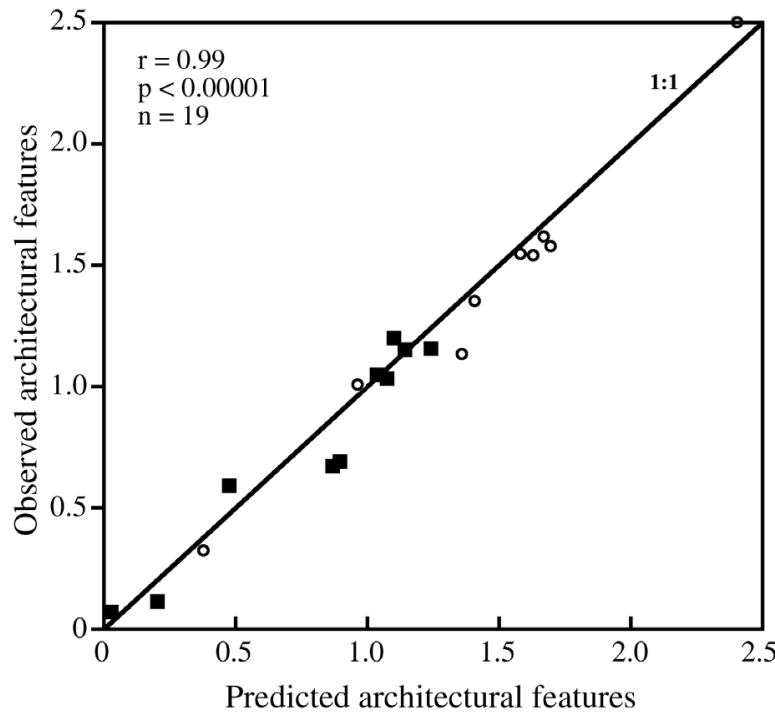

Fig. 3. Zostera noltii (n) and Cymodocea nodosa (0). Logarithmic transformed data for simulated vs observed architectural traits. Continuous line represents 1:1 relationship for plotted data. See Tables 3 and 5 for further details

ent enrichment also promoted indirect effects such as shading by enhancing growth of ephemeral algae (phytoplankton, macroalgae and epiphytes; Short et al. 1995). Other studies recorded direct toxic effects when the nutrient supply (ammonium) exceeded the seagrasses' buffering capacity (van Katwijk et al. 1997, Brun et al. 2002). Studies relating hydrodynamic characteristics with dynamic parameters, shoot morphology and meadow properties were mainly concerned with field observations, and the variability in the results precluded generalisation of the response at different levels (dynamic parameters, shoot morphometry, meadow properties; Table 5).

\section{DISCUSSION}

The present study has established that plant morphology and meadow properties may depend on a few, easily measurable, growth dynamic parameters (PI, RER, LER) that may be 'tuned' at the seagrassmodule level to cope with environmental constraints (Table 5). Species with a large adjustment capacity will have a high phenotypic plasticity in morphological traits and can be considered as ecological generalists, whereas those with a fairly limited acclimation plasticity may be restricted to narrower ecological ranges (sensu Sultan 1995). Limits for phenotypic plasticity depend on the underlying genotype that imposed the 'norm of reaction' for each individual under diverse environments (Sultan 1995, 2000). This means that if limits for the input parameters used in the model are estimated for a given seagrass population (i.e. PI, LER, RER), its potential capacity to respond morphologically to a particular environmental forcing, and therefore its habitat requirements, can be predicted. In this context, various authors have found evidence that plant morphometric features are closely related to their habitat characteristics (Short 1983, Peralta et al. 2000, Brun et al. 2003c, Durako \& Hackney 2004). Therefore, if it is established how and/or which abiotic factors affect plant morphology, differences in morphological features can be used as indicators to assess variations in abiotic conditions, providing a 'natural' range of morphological features. Once this range has been determined, comparisons between measured versus expected morphology are possible through field-sampling programmes. Large discrepancies might well serve as an early warning (a symptom) of environmental disturbance; and be used in conjunction with the current physiological (fluorescence, internal nutrient composition, non-structural carbohydrates, etc.) and ecological (shoot density, canopy height, primary production, etc.) warning indicators.

Both Zostera noltii and Cymodocea nodosa showed similar variability in architectural, dynamic and meadow attributes, although the former has been previously considered to play a pioneer role and, thereby, to have a larger plasticity than C. nodosa (Duarte 1991, Marbá \& Duarte 1998). However, we hypothesise that despite the similar plasticity of both species, $Z$. noltii will have larger plasticity in morphological and population properties on a temporal scale. The time span necessary for a complete turnover of a shoot's morphology (i.e the period required to renew all leaves within a shoot) is generally $4 \times \mathrm{PI}$ (32 and $80 \mathrm{~d}$ on average for $Z$. noltii and C. nodosa, respectively). In addition, for apical shoots of $Z$. noltii, recruitment of 1 new shoot is expected to occur in each plastochrone interval, since this species produces 1 shoot in each node. In contrast, shoot recruitment is more variable in C. nodosa. As shown for terrestrial clonal plants, plasticity is advantageous when plant response-time and duration of the disturbance are on similar temporal scales (Stuefer et al. 1996, DeWitt et al. 1998, Alpert \& Simms 2002). Although potential morphological plasticity is similar in both species, temporal plasticity is expected to be higher in $Z$. noltii and for short-PI species in general. This agrees with the faster response $(<2 \mathrm{wk})$ of $Z$. noltii and other small species to shading, burial, recolonisation and experimental nutrient manipulation (Rollon et al. 1998, Longstaff \& Deninson 1999, Brun et al. 2002, 2003b,c, 2005, Peralta et al. 2002, 2005), especially when compared to the longer response time ( $>5 \mathrm{mo}$ ) observed in long-PI species (Bulthuis 1983, Neverauskas 1988, Marbá et al. 1994, Rollon et al. 1998, Ruíz 
Table 5. Overview of general results of studies on seagrasses subjected to light reduction, nutrient enrichment and different water-flow characteristics. Comparisons of light reduction were between control (or shallower populations) and lowest light levels (or deeper populations); comparisons of nutrient enrichment were between control and highest nutrient treatments; comparisons in water-flow characteristics were between low and high velocities or turbulences. + : increment; - : reduction; $=:$ no differences; PI: plastochrone index; LER: leaf elongation rate; RER: rhizome elongation rate; LL: leaf length; LW: leaf width; LA: leaf area; IL: internode length; TB: total biomas; AB: above-ground biomass; BB: below-ground biomass; Density: shoot density. 1: Abal et al. (1994); 2: Agawin et al. (1996); 3: Alcoverro et al. (1997); 4: Bach et al. (1998); 5: Backman \& Barilotti (1976); 6: Bandeira (2002); 7: Bintz \& Nixon (2001); 8: Brun et al. (2002); 9: Brun et al. (2003c); 10: Bulthuis (1983); 11: Bulthuis \& Woelkerling (1981); 12: Dalla Via et al. (1998); 13: Dawes (1998); 14: Denninson \& Alberte (1982); 15: Dennison \& Alberte (1986); 16: Czerny \& Dunton; 17: Fitzpatrick \& Kirman (1995); 18: Fonseca \& Kenworthy (1987): 19: Gordon et al. (1994); 20: Harlin \& Thorne-Miller (1981); 21: Holmer \& Laursen (2002): 22: Kraemer \& Hanisak (2000); 23: Lee \& Dunton (1997); 24: Lee \& Dunton (2000); 25: Longstaff \& Dennison (1999); 26: Middelboe et al. (2003); 27: Moore et al. (1997); 28: Murray et al. (1992); 29: Neverauskas (1988); 30: Olesen \& SandJenses (1993); 31: Olesen et al. (2002); 32: Orth (1977); 33: Peralta et al. (2000); 34: Peralta et al. (2002); 35: Peralta et al. (2003); 36: Peralta et al. (2005); 37: Peralta et al. (2006); 38: Pérez et al. (1991); 39: Pérez et al. (1994); 40: Phillipart (1995); 41: Powell et al. (1989); 42: Roberts et al. (1984); 43: Ruíz \& Romero (2001); 44: Schanz \& Asmus (2003); 45: Schwarz \& Hellblom (2002); 46: Shafer (1999); 47: Short (1983); 48: Short (1987); 49: Short et al. (1995); 50: Short et al. (1990); 51: Terrados et al. (1999); 52: Tomasko(1992); 53: van Katwijk et al. (1997); 54: van Katwijk et al. (1998); 55: van Lent et al. (1995); 56: West et al. (1990)

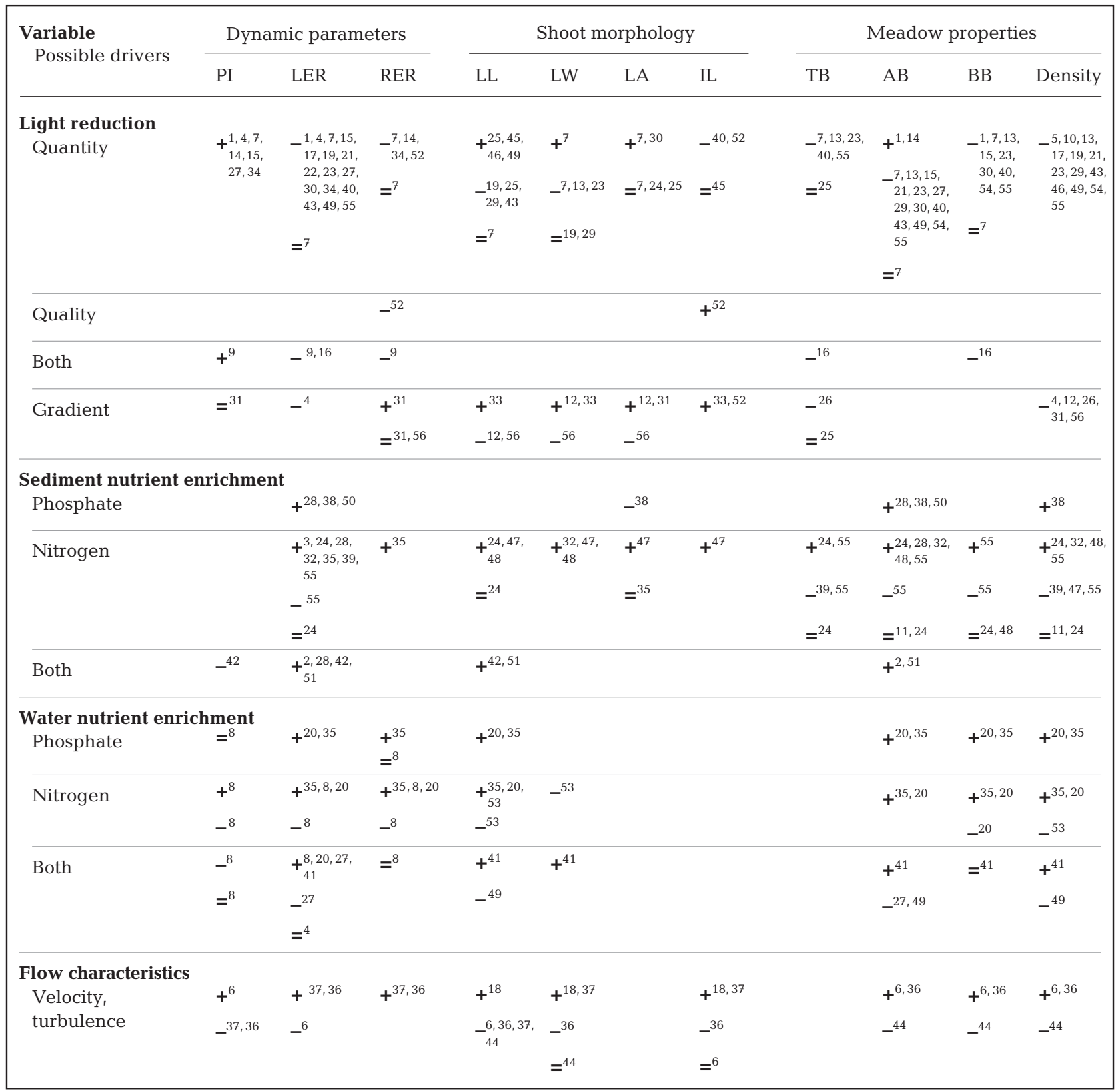


\& Romero 2001). In contrast to the faster response of short-PI species, clonal integration is expected to be higher in long-PI species (Duarte 1991, Marbá et al. 2002) and and can counterbalance, or at least modulate, environmental constraints by allowing plants to buffer environmental variations (Tomasko \& Dawes 1989). However, at present, experimental data scaling clonal integration and plant size are still rare (Marbá et al. 2002). Such studies are necessary to determine the importance of clonal integration in regulating the module response to phylloclimate and, ultimately, whole-plant response (de Kroon et al. 2005).

An individual-based model, using simple growth rules at the module level together with natural variability in the dynamic growth parameters, enabled us to provide an accurate description of intra- and interspecific plasticity in architectural traits and, to a lesser extent, meadow properties of seagrass populations. Variability in dynamic parameters is responsible for intra- and interspecific morphological differences. Species with long PIs will have larger leaves and standing-crop biomass but lower shoot densities than species with shorter PIs. This agrees with the allometric scaling between PI and module sizes described for a large number of seagrass species by Duarte (1991) and with the negative relationship between shoot size and density indicated by the 'self-thinning' law (Duarte \& Kalff 1987, Weller 1987, Matthew et al. 1995). Although this simple model describes accurately species-specific properties at the meadow level, the simulated values were, in general, higher than those observed. This divergence was expected since the model does not consider density-dependence processes or loss mechanisms, and therefore 'overcrowding' is likely to occur in the simulated meadow attributes. Furthermore, meadow properties also depend on branching frequency and angle, and on the proportion of nodes bearing shoots (Marbá \& Duarte 1998, Brun et al. 2006, Sintes et al. 2005). Although these factors are crucial for seagrass development, they are currently modelled as stochastic processes, despite evidence showing that they are tightly regulated (in speciesspecific, and on seasonal and spatial scales, Duarte \& Sand-Jensen 1990, Vermaat \& Verhagen 1996, Marbá \& Duarte 1998, Marbá \& Walker 1999, Brun et al. 2003a) and possibly related to dynamic parameters (Brun et al. 2005b).

Simple theoretical predictions based on this model suggest that plants sense their surrounding environments (abiotic and biotic), and that regulation occurs at the module level by concomitant changes in the dynamic growth parameters and morphometric and meadow properties (Table 5). As plant growth and meadow expansion is a continuous temporal process, progressive variations in self-shading, nutrient budget and/or hydrodynamic conditions will occur as a result of plant growth (Fonseca et al. 1982, Duarte \& SandJensen 1990, Pedersen et al. 1997). Furthermore, the combination of spatio-temporal gradients in resource availability (light, nutrients, current, space, etc.) implies that the observed (actual) phenotypic and meadow attributes may be highly complex. For instance, enhancement of growth rates, biomass and shoot density following a nutrient enrichment episode (Table 5) will affect light climate within the canopy (i.e. increase self-shading and competitiveness for light and space) and hydrodynamics. This will make plants respond at the module level by continuously adjusting morphology and meadow properties to the phylloclimate (Table 5; Fig. 4). It should generate a recurrent feedback loop between biotic and abiotic conditions with several stationary or equilibrium states until surrounding conditions again change, as shown for the seagrass Zostera noltii after recovery from a severe humaninduced disturbance episode (Peralta et al. 2005). This hypothesis, whereby the response at the module level to the phylloclimate may reflect the whole-plant response, agrees fairly well with the recent suggestions by de Kroon et al. (2005) that 'the response of the whole plant to its environment is the sum of all the modular responses plus all interaction effects that are due to integration'.

Dynamic growth parameters are easily measurable using field sampling and/or experimental procedures. Table 5 shows specific responses of plant dynamic parameters to main environmental cues (light and nutrients). These responses allow the incorporation of

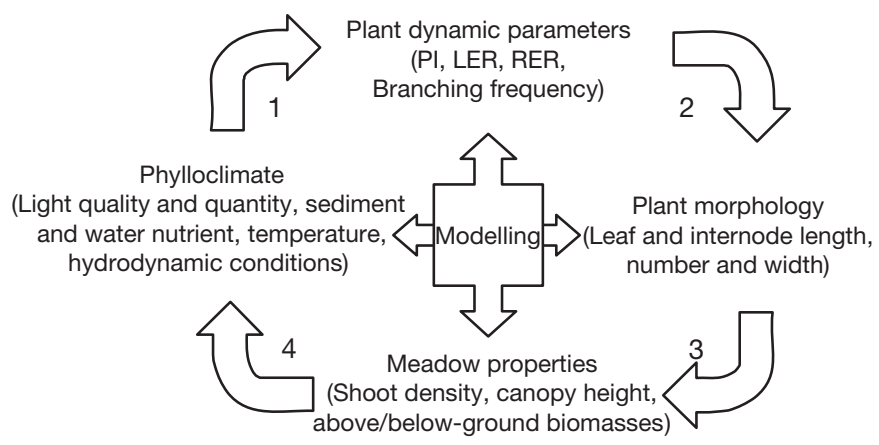

Fig. 4. Simple schematic framework illustrating how complex functional-structural seagrass models (FSSMs) may be built using simple growth rules at module level, and plant dynamic parameters, phylloclimate and feedbacks between biotic and abiotic elements. 1: Phylloclimate regulates plant dynamic parameters at module level; 2: plant dynamic parameters yield individual module and plant morphology; 3: wholeplant morphology and ultimately meadow attributes arise from sum of all individual modular responses; 4: heterogeneous meadow attributes modify phylloclimate variables which, in turn, influence plant dynamic parameters 
plant morphology into complex, spatial explicit models (e.g. Marbá \& Duarte 1998, Sintes et al. 2005), in which feedback mechanisms depending on canopy morphometry, neighbouring shoots and phylloclimate (for example light-canopy distribution; Zimmerman 2003) are included. However, to progress from the current state, 2 basic types of functions are required: (1) to describe how a plant element (leaf, rhizome, root, etc.) influences its surroundings, and on what physical scale, and (2) to assess the influence of the environment (light, temperature, nutrients, hydrodynamics, etc.) on plant dynamic parameters. Despite the importance of both types of functions, data on them are virtually absent from the seagrass literature, and they deserve future research.

In conclusion, plant morphology arises as an emergent property of a simple set of growth rules acting at the module level. These growth rules can be easily incorporated into FSSMs, with feedbacks among plant morphology, plant development and phylloclimate being modelled using plant dynamic parameters. Intra- and interspecific morphological plasticity observed in seagrasses as well as some meadow attributes may be accurately described and predicted using a limited number of plant dynamic parameters (PI, LER, RER). Variability in the dynamic parameters can be a good estimator of the morphological limits of a given seagrass population.

Acknowledgements. F.G.B. is supported by an individual Marie Curie fellowship (EU contract MEIF-CT-2005-515071). This work was also funded by the Spanish Projects REN200200746/MAR and CTM2005-00395/MAR. M.P.G.-S. holds an FPI from the Ministerio de Educación y Ciencia. The authors also acknowledge help provided by Maria Fernanda Murillo and Manuel Campo, valuable suggestions of T. Bouma and P. Herman in a previous version of the manuscript, and the constructive comments of 3 anonymous referees. This is NIOO Publication No. 3782.

\section{LITERATURE CITED}

Abal EG, Loneragan N, Bowen P, Perry CJ, Udy JW, Dennison WC (1994) Physiological and morphological responses of the seagrass Zostera Capricorni Aschers. to light intensity. J Exp Mar Biol Ecol 178:113-129

Agawin NSR, Duarte CM, Fortes MD (1996) Nutrient limitation of Philippine seagrasses (Cape Bolinao, NW Philippines): in situ experimental evidence. Mar Ecol Prog Ser 138:233-243

Alcoverro T, Duarte CM, Romero J, López NI (1997) Spatial and temporal variations in nutrient limitation of seagrass Posidonia oceanica growth in the NW Mediterranean. Mar Ecol Prog Ser 146:155-161

Alpert P, Simms EL (2002) The relative advantages of plasticity and fixity in different environments: When is it good for a plant to adjust? Evol Ecol 16:285-297

Bach SS, Borum J, Fortes MD, Duarte CM (1998) Species composition and plant performance of mixed seagrass beds along a siltation gradient at Cape Bolinao, The Philippines. Mar Ecol Prog Ser 174:247-256

Backman TW, Barilotti DC (1976) Irradiance reduction: effects on standing crops of the eelgrass Zostera marina in a coastal lagoon. Mar Biol 34:33-40

Bandeira SO (2002) Leaf production rates of Thalassodendron ciliatum from rocky and sandy habitats. Aquat Bot 72: $13-24$

Bell AD (1991) Plant form - an illustrated guide to flowering plant morphology. Oxford University Press, Oxford

Bintz JC, Nixon SW (2001) Responses of eelgrass Zostera marina seedlings to reduced light. Mar Ecol Prog Ser 223: 133-141

Bos HJ, Neuteboom JH (1998) Morphological analysis of leaf and tiller number dynamics of wheat (Triticum aestivum L.): responses to temperature and light intensity. Ann Bot Fenn 81:131-139

Brun FG (2004) Role of the non-structural carbohydrates and morphological variations on the acclimation response of the seagrass Zostera noltii against environmental constraints. Integration in predictive models. $\mathrm{PhD}$ thesis, Cádiz University

Brun FG, Vergara JJ, Hernández I, Peralta G, Pérez-Lloréns JL (2002) Assessing the toxicity of ammonium pulses in the survival and growth of Zostera noltii. Mar Ecol Prog Ser 225:177-187

Brun FG, Pérez-Lloréns JL, Vergara JJ, Hernández I (2003a) Patch distribution and within-patch dynamics of the seagrass Zostera noltii Hornem at Los Toruños salt-marsh (Cádiz Bay, Natural Park, Spain). Bot Mar 46:513-524

Brun FG, Vergara JJ, Hernández I, Pérez-Lloréns JL (2003b) Growth, carbon allocation and proteolytic activity in the seagrass Zostera noltii shaded by Ulva canopies. Funct Plant Biol 30:551-560

Brun FG, Vergara JJ, Navarro G, Hernández I, Pérez-Lloréns JL (2003c) Effect of shading by Ulva rigida canopies on growth and carbon balance of the seagrass Zostera noltii. Mar Ecol Prog Ser 265:85-96

Brun FG, Vergara JJ, Hernández I, Pérez-Lloréns JL (2005) Evidence for vertical growth in Zostera noltii Hornem. Bot Mar 48:446-450

Brun FG, Pérez-Pastor A, Hernández I, Vergara JJ, PérezLloréns JL (2006) Ecological implications of shoot organisation in the seagrass Zostera noltii. Helgol Mar Res 60:59-69

Bulthuis DA (1983) Effects of in situ light reduction on density and growth of the seagrass Heterozostera tasmanica (Martens Ex Aschers) Den Hartog in Western Port, Victoria, Australia. J Exp Mar Biol Ecol 67:91-103

Bulthuis DA, Woelkerling WJ (1981) Effects of in situ nitrogen and phosphorus enrichment of the sediments on the seagrass Heterozostera tasmanica (Martens ex Aschers.) den Hartog in Western Port, Victoria, Australia. J Exp Mar Biol Ecol 53:193-207

Chelle M (2005) Phylloclimate or the climate perceived by individual plant organs: What is it? How to model it? What for? New Phytol 166:781-790

Czerny AB, Dunton KH (1995) The effects of in situ light reductions on the growth of two subtropical seagrasses, Thalassia testudinum and Halodule wrightii. Estuaries 18: 418-427

Dalla Via J, Sturmbauer C, Schönweger G, Sötz E, Mathekowitsch S, Stifter M, Rieger R (1998) Light gradients and meadow structure in Posidonia oceanica: ecomorphological and functional correlates. Mar Ecol Prog Ser 163: $267-278$ 
Dawes CJ (1998) Biomass and photosynthetic responses to irradiance by a shallow and deep water population of Thalassia testudinum on the west coast of Florida. Bull Mar Sci 62:89-91

de Kroon H, Schieving F (1991) Resource-allocation patterns as a function of clonal morphology - a general-model applied to a foraging clonal plant. J Ecol 79:519-530

de Kroon H, Huber H, Stuefer JF, van Groenendael JM (2005) A modular concept of phenotypic plasticity in plants. New Phytol 166:73-82

den Hartog C (1970) The seagrasses of the world. NorthHolland, Amsterdam

Dennison WC, Alberte RS (1982) Photosynthetic responses of Zostera marina L. (eelgrass) to in situ manipulation of light intensity. Oecologia 55:137-144

Dennison WC, Alberte RS (1986) Photoadaptation and growth of Zostera marina L. (eelgrass) transplants along a depth gradient. J Exp Mar Biol Ecol 98:265-282

DeWitt TJ, Sih A, Wilson DS (1998) Cost and limits of phenotypic plasticity. Trends Ecol Evol 13:77-81

Duarte CM (1991) Allometric scaling of seagrass form and productivity. Mar Ecol Prog Ser 77:289-300

Duarte CM, Kalff J (1987) Weight-density relationships in submerged macrophytes. The importance of light and plant geometry. Oecologia 72:612-617

Duarte CM, Sand-Jensen K (1990) Seagrass colonisation: biomass and shoot demography in Cymodocea nodosa patches. Mar Ecol Prog Ser 67:97-103

Durako MJ, Hackney JW (2004) Size-frequency patterns in morphometric characteristics of the seagrass Thalassia testudinum reflect environmental variability. Ecol Indicators 4:55-71

Evans JP, Cain ML (1995) A spatially explicit test of foraging behavior in a clonal plant. Plant Ecol 76:1147-1155

Fitzpatrick J, Kirkman H (1995) Effects of prolonged shading stress on growth and survival of seagrass Posidonia australis in Jervis Bay, New South Wales, Australia. Mar Ecol Prog Ser 127:279-289

Fonseca MS, Kenworthy WJ (1987) Effects of current on photosynthesis and distribution of seagrasses. Aquat Bot 27: $59-78$

Fonseca MS, Fisher JS, Zieman JC, Thayer GW (1982). Influence of the seagrass, Zostera marina L., on current flow. Estuar Coast Shelf Sci 15:351-358

Gordon DM, Grey KA, Chase SC, Simpson CJ (1994) Changes to the structure and productivity of a Posidonia sinuosa meadow during and after imposed shading. Aquat Bot 47:265-275

Grime JP, Mackey JML (2002) The role of plasticity in resource capture by plants. Evol Ecol 16:299-307

Groenendael JM, Klimes L, Klimesova J, Hendriks RJJ (1996) Comparative ecology of clonal plants. Philos Trans R Soc Lond A 351:1331-1339

Harlin MM, Thorne-Miller B (1981) Nutrient enrichment of seagrass beds in a Rhode Island coastal lagoon. Mar Biol 65:221-229

Harper JL, Bell AD (1979) The population dynamics of growth form in organisms with modular construction. In: Anderson RM, Turner BD, Taylor LR (eds) Population dynamics. Symp Bri Ecol Soc No. 20. Blackwell Scientific Publications, Oxford, p 29-52

Hemminga MA, Duarte CM (2000) Seagrass Ecology. Cambridge University Press, Cambridge, UK

Herben T, Suzuki JI (2001) A simulation study of the effects of architectural constraints and resource translocation on population structure and competition in clonal plants. Evol Ecol 15:403-423
Holmer M, Laursen L (2002) Effect of shading of Zostera marina (eelgrass) on sulfur cycling in sediments with contrasting organic matter and sulfide pools. Aquat Bot 270: $25-37$

Horn H (1971) The adaptive geometry of trees. Princeton University Press, Princeton, NJ

Huber H, Lukacs S, Watson MA (1999) Spatial structure of stoloniferous herbs: an interplay between structural blueprint, ontogeny and phenotypic plasticity. Plant Ecol 141: $107-115$

Iizumi H, Hattori A, McRoy CP (1980) Nitrate and nitrite in interstitial waters of eelgrass beds in relation to the rhizosphere. J Exp Mar Biol Ecol 47:191-201

Kentula ME, Dewitt TH (2003) Abundance of seagrass (Zostera marina L.) and macroalgae in relation to the salinity-temperature gradient in Yaquina Bay, Oregon, USA. Estuaries 26: 1130-1141

Koch EM (2001) Beyond light: physical, geological, and geochemical parameters as possible submersed aquatic vegetation habitat requirements. Estuaries 24:1-17

Kraemer GP, Hanisak DM (2000) Physiological and growth responses of Thalassia testudinum to environmentallyrelevant periods of low irradiance. Aquat Bot 67:287-300

Lee KS, Dunton KH (1997) Effects of in situ light reduction on the maintenance, growth and partitioning of carbon resources in Thalassia testudinum Banks ex König. J Exp Mar Biol Ecol 210:53-73

Lee K, Dunton KH (2000) Diurnal changes in pore water sulfide concentrations in the seagrass Thalassia testudinum beds: the effects of seagrasses on sulfide dynamics. J Exp Mar Biol Ecol 255:201-214

Longstaff BJ, Dennison WC (1999) Seagrass survival during pulsed turbidity events: the effects of light deprivation on the seagrasses Halodule pinifolia and Halophila ovalis. Aquat Bot 65:105-121

Marbà N, Duarte CM (1998) Rhizome elongation and seagrass clonal growth. Mar Ecol Prog Ser 174:269-280

Marbà N, Walker DI (1999) Growth, flowering, and population dynamics of temperate Western Australian seagrasses. Mar Ecol Prog Ser 184:105-118

Marbà N, Cebrian J, Enriquez S, Duarte CM (1994) Migration of large-scale subaqueous bedforms measured with seagrasses (Cymodocea nodosa) as tracers. Limnol Oceanogr 39:126-133

Marbà N, Hemminga MA, Mateo MA, Duarte CM, Mass YEM, Terrados J, Gacia E (2002) Carbon and nitrogen translocation between seagrass ramets. Mar Ecol Prog Ser 226:287-300

Masini RJ, Manning CR (1997) The photosynthetic responses to irradiance and temperature of four meadow-forming seagrasses. Aquat Bot 58:21-36

Matthew C, Lemaire G, Sackville NR, Hernández A (1995) A modified self-thinning equation do describe size/density relationships for defoliated swards. Ann Bot Fenn 76: 579-587

Middelboe AL, Sand-Jensen K, Krause-Jensen D (2003) Spatial and interannual variations with depth in eelgrass populations. J Exp Mar Biol Ecol 291:1-15

Moore KA, Wetzel RL, Orth RJ (1997) Seasonal pulses of turbidity and their relations to eelgrass (Zostera marina L.) survival in an estuary. J Exp Mar Biol Ecol 215:115-134

Murray L, Dennison WC, Kemp WM (1992) Nitrogen versus phosphorus limitation for growth of an estuarine population of eelgrass (Zostera marina). Aquat Bot 44: 83-100

Neverauskas VP (1988) Response of a Posidonia community to prolonged reduction in light, Aquat Bot 31:361-366 
Oborny B (1994) Growth rules in clonal plants and environmental predictability: a simulation study. J Ecol 82: $341-351$

Oborny B (2004) External and internal control in plant development. Adaptive plasticity in plants. Complexity 9(3): $22-28$

Oborny B, Czaran T, Kun A (2001) Exploration and exploitation of resource patches by clonal growth: a spatial model on the effect of transport between modules. Ecol Model 141:151-169

Olesen B, Sand-Jensen K (1993) Seasonal acclimatization of eelgrass Zostera marina growth to light. Mar Ecol Prog Ser 94:91-99

Olesen B, Enriquez S, Duarte CM, Sand-Jensen K (2002) Depth-acclimation of photosynthesis, morphology and demography of Posidonia oceanica and Cymodocea nodosa in the Spanish Mediterranean Sea. Mar Ecol Prog Ser 236:89-97

Orth RJ (1977) Effect of nutrient enrichment on growth of the eelgrass Zostera marina in the Chesapeake Bay, Virginia, USA. Mar Biol 44:187-194

Ostenfeld CH (1908) On the ecology and distribution of the grass-wrack (Zostera marina) in Danish waters. Rep Dan Biol Stn 16:1-62

Pedersen MF, Duarte CM, Cebrian J (1997) Rates of changes in organic matter and nutrient stocks during seagrass Cymodocea nodosa colonisation and stand development. Mar Ecol Prog Ser 159:29-36

Peralta G, Pérez-Lloréns JL, Hernández I, Vergara JJ, Bartual A, Brun FG, Gálvez JA, García CM (2000) Morphological and physiological differences of 2 morphotypes of Zostera noltii Hornem. from the southwestern Iberian Peninsula. Helgol Mar Res 54:80-86

Peralta G, Pérez-Lloréns JL, Hernández I, Vergara JJ (2002) Effects of light availability on growth, architecture and nutrient content of the seagrass Zostera noltii Hornem. J Exp Mar Biol Ecol 269:9-26

Peralta G, Bouma TJ, van Soelen J, Perez-Llorens JL, Hernandez I (2003) On the use of sediment fertilisation for seagrass restoration: a mesocosm study on Zostera marina L. Aquat Bot 75:95-110

Peralta G, Brun FG, Pérez-Lloréns JL, Hernández I, Vergara JJ (2005) Morphometric variations as acclimation mechanisms in the seagrass Zostera noltii: biological effects of coastal engineering works. Estuar Coast Shelf Sci 64: 347-356

Peralta G, Brun FG, Pérez-Lloréns, Bouma TJ (2006) Current velocity directly affects growth, morphometry and architecture of the seagrass Zostera noltii. Mar Ecol Prog Ser (in press)

Pérez M, Romero J, Duarte CM, Sand-Jensen K (1991) Phosphorus limitation of Cymodocea nodosa growth. Mar Biol 109:129-133

Pérez M, Duarte CM, Romero J, Sand-Jensen K, Alcoverro T (1994) Growth plasticity in Cymodocea nodosa stands: the importance of nutrient supply. Aquat Bot 47:249-264

Pérez-Lloréns JL, Niell FX (1991) Variaciones estacionales de biomasa foliar, índice foliar y biomasa subterránea en la fanerógama acuática Zostera noltii Hornem. en el estuario del río Palmones (Cádiz). In: Cruz L, Morales R, Sánchez P, Castillo P (eds) Actas del VI Congreso Español de Limnología, Granada University Science Press, Granada, p 253-260

Pérez-Lloréns JL, Niell FX (1993) Temperature and emergence effects on the net photosynthesis of two Zostera noltii Hornem. morphotypes. Hydrobiologia 254:53-64

Philippart CJM (1995) Effect of periphyton grazing by Hydro- bia ulvae on the growth of Zostera noltii on a tidal flat in the Dutch Wadden Sea. Mar Biol 122:431-437

Phillips RC, Lewis RR (1983) Influence of environmental gradients in leaf widths and transplant success in North American seagrasses. Mar Technol Soc J 17:59-68

Powell GVN, Kenworthy WJ, Fourqurean JW (1989) Experimental evidence for nutrient limitation of seagrass growth in a tropical estuary with restricted circulation. Bull Mar Sci 44:324-340

Roberts MH, Orth W, Moore KA (1984) Growth of Zostera marina L. seedlings under laboratory conditions of nutrient enrichment. Aquat Bot 20:321-328

Rollon RN, Van Steveninck EDD, Van Vierssen W, Fortes MD (1998) Contrasting recolonisation strategies in multi-species seagrass meadows. Mar Pollut Bull 37:450-459

Ruiz JM, Romero J (2001) Effects of in situ experimental shading on the Mediterranean seagrass Posidonia oceanica. Mar Ecol Prog Ser 215:107-120

Schanz A, Asmus H (2003) Impact of hydrodynamics on development and morphology of intertidal seagrasses in the Wadden Sea. Mar Ecol Prog Ser 261:123-134

Schwarz AM, Hellblom F (2002) The photosynthetic light response of Halophila stipulacea growing along a depth gradient in the Gulf of Aqaba, the Red Sea. Aquat Bot 74:263-272

Schlichting CD (1986) The evolution of phenotypic plasticity in plants. Annu Rev Ecol Syst 17:667-693

Seddon S, Cheshire AC (2001) Photosynthetic response of Amphibolis antarctica and Posidonia australis to temperature and desiccation using chlorophyll fluorescence. Mar Ecol Prog Ser 220: 119-130

Shafer DJ (1999) The effects of dock shading on the seagrass Halodule wrightii in Perdido Bay, Alabama. Estuaries 22:936-943

Short FT (1983) The seagrass, Zostera marina L.: plant morphology and bed structure in relation to sediment ammonium in Izembek Lagoon, Alaska. Aquat Bot 16:149-161

Short FT (1987) Effects of sediment nutrients on seagrasses: literature review and mesocosm experiment. Aquat Bot 27:41-57

Short FT, Dennison WC, Capone DG (1990) Phosphorus-limited growth of the tropical seagrass Syringodium filiforme carbonate sediments. Mar Ecol Prog Ser 62:169-174

Short FT, Burdick DM, Kaldy JE (1995) Mesocosm experiments quantify the effects of eutrophication on eelgrass, Zostera marina. Limnol Oceanogr 40:740-749

Sintes T, Marba N, Duarte CM, Kendrick GA (2005) Nonlinear processes in seagrass colonisation explained by simple clonal growth rules. Oikos 108:165-175

Slade AJ, Hutchings MJ (1987) The effects of light intensity on foraging in the clonal herb. J Ecol 75:639-650

Stuefer JF, During HJ, de Kroon H (1994) High benefits of clonal integration in two stoloniferous species, in response to heterogeneous light environments. J Ecol 82:511-518

Stuefer JF, DeKroon H, During HJ (1996) Exploitation of environmental heterogeneity by spatial division of labour in a clonal plant. Funct Ecol 10:328-334

Sultan SE (1995) Phenotypic plasticity and plant adaptation. Acta Bot Neerl (Spec Jubilee Symp) 44:363-383

Sultan SE (2000) Phenotypic plasticity for plant development, function and life history. Trends Plant Sci 5:538-542

Terrados J, Agawin NSR, Duarte CM, Fortes MD, KampNielsen L, Burum J (1999) Nutrient limitation of the tropical seagrass Enhalus acoroides (L.) Royle in Cape Bolinao, NW Philippines. Aquat Bot 65:123-139

Tomasko DA (1992) Variations in growth form of shoal grass (Halodule wrightii) due to changes in spectral composition 
of light below a canopy of turtle grass (Thalassia testudinum). Estuaries 15:214-217

Tomasko DA, Dawes CJ (1989) Evidence for physiological integration between shaded and unshaded shoots of Thalassia testudinum. Mar Ecol Prog Ser 54:299-305

Tomlinson PB (1974) Vegetative morphology and meristem dependence. The foundation of productivity in seagrasses. Aquaculture 4:107-130

Tomlinson PB (1982) Helobiae (Alismatidae). In: Metcalfe CR (ed) Anatomy of the monocotyledons, Vol 7. Clarendon Press, Oxford

Touchette BW, Burkholder JM (2002) Seasonal variations in carbon and nitrogen constituents in eelgrass (Zostera marina L.) as influenced by increased temperature and water-column nitrate. Bot Mar 45: 23-34

Urbas P, Zobel K (2000) Adaptative and inevitable morphological plasticity of three herbaceous species in a multispecies community: field experiment with manipulated nutrient and light. Acta Oecol 21:139-147

van Katwijk MM, Vergeer LHT, Schmitz GHW, Roelofs JGM (1997) Ammonium toxicity in eelgrass Zostera marina. Mar Ecol Prog Ser 157:159-173

van Katwijk MM, Schmitz GHW, Hanssen LSAM, den Hartog C (1998) Suitability of Zostera marina populations for transplantation to the Wadden Sea as determined by a mesocosm shading experiment. Aquat Bot 60:283-305

van Lent F, Verschuure JM (1994a) Intraspecific variability of

Editorial responsibility: Otto Kinne (Editor-in-Chief), Oldendorf/Luhe, Germany
Zostera marina L. (eelgrass) in the estuaries and lagoons of the southwestern Netherlands. I. Population dynamics. Aquat Bot 48:31-58

van Lent F, Verschuure JM (1994b) Intraspecific variability of Zostera marina L. (eelgrass) in the estuaries and lagoons of the southwestern Netherlands. II. Relation with environmental factors. Aquat Bot 48:59-75

van Lent F, Verchuure JM, Van Veghel LJ (1995) Comparative study on populations of Zostera marina L. (eelgrass): in situ nitrogen enrichment and light manipulation. J Exp Mar Biol Ecol 185:55-76

Vermaat JE, Verhagen FCA (1996) Seasonal variation in the intertidal seagrass Zostera noltii Hornem: coupling demographic and physiological patterns. Aquat Bot 52:259-281

Waller DM (1986) The dynamics of growth and form. In: Crawley MJ (ed) Plant ecology. Blackwell Scientific Publications, Oxford, p 291-320

Weller DE (1987) A reevaluation of the -3/2 power rule of selfthinning. Ecol Monogr 57:23-43

West RJ, Jacobs NE, Roberts DE (1990) Experimental transplanting of seagrasses in Botany Bay, Australia. Mar Pollut Bull 21:197-203

White J (1979) The plant as a metapopulation. Annu Rev Ecol Syst 10:109-145

Zimmerman RC (2003) A biooptical model of irradiance distribution and photosynthesis in seagrass canopies. Limnol Oceanogr 48:568-585

Submitted: October 25, 2004; Accepted: January 25, 2005

Proofs received from author(s): September 11, 2006 